DOI: 10.22630/EIOGZ.2014.108.46

Zeszyty Naukowe Szkoły Głównej Gospodarstwa Wiejskiego

Ekonomika i Organizacja Gospodarki Żywnościowej nr 108, 2014: 145-158

Katarzyna Łukiewska

Katedra Ekonomiki Przedsiębiorstw

Uniwersytet Warmińsko-Mazurski w Olsztynie

\title{
Wpływ wybranych czynników w Polsce na produktywność zasobów w przetwórstwie przemysłowym ze szczególnym uwzględnieniem przetwórstwa żywności
}

\section{Wstęp}

Produktywność należy do elementarnych kategorii w naukach ekonomicznych. Wyraża efektywność ponoszonych nakładów i ma kluczowe znaczenie dla rozwoju gospodarek narodowych, gałęzi i indywidualnych przedsiębiorstw. W analizie konkurencyjności przemysłowej traktowana jest jako ważna determinanta zwiększania produkcji. Wzrost produktywności czynników produkcji jest podstawą przetrwania i rozwoju przedsiębiorstwa w dłuższym okresie i równocześnie czynnikiem kształtującym jego bieżącą i przyszłą wartość. Z tego względu wielu ekonomistów utożsamia produktywność z konkurencyjnością. Rachunek produktywności obejmuje podstawowe relacje zachodzące między produkcją a czynnikami produkcji zaangażowanymi w działalności przedsiębiorstwa. Teoria produktywności rozwinęła się w kierunku mierzenia wydajności poszczególnych czynników produkcji (np. pracy, kapitału, nakładów pośrednich i innych rodzajów nakładów), czyli tzw. produktywności cząstkowej oraz pomiaru łącznej wydajności wszystkich rodzajów nakładów, czyli tzw. produktywności całkowitej. Szczególne miejsce w analizie produktywności ma określenie czynników kształtujących jej poziom i wzrost. Celem badań była ocena poziomu wybranych czynników produktywności oraz ich wpływu na produktywność pracy, kapitału i produktywność całkowitą w przemyśle spożywczym na tle przetwórstwa przemysłowego w latach 1995-2011 . 


\section{6}

\section{Metodyka badań}

Do pomiaru produktywności zastosowano wskaźniki produktywności cząstkowej oraz całkowitej. Produktywność cząstkowa wyraża efektywność poszczególnych nakładów wykorzystywanych w produkcji i jest stosunkiem całkowitej ilości wytworzonych dóbr do ilości poszczególnych rodzajów czynników wytwórczych użytych do ich wytworzenia. W pracy obliczono produktywność pracy i kapitału zgodnie z następującymi wzorami:

\section{$V / L, \quad V / K$}

gdzie:

$V$ - wartość dodana,

$L$ - przeciętne zatrudnienie,

$K$ - wartość brutto środków trwałych.

Produktywność całkowita wyraża natomiast efektywność łącznie wszystkich czynników produkcji. Łączną produktywność czynników produkcji oszacowano na podstawie koncepcji neoklasycznej funkcji produkcji Cobba-Douglasa:

$$
V=A_{0} L^{\alpha_{1}} K^{\alpha_{2}}
$$

gdzie:

$A_{0}>0$ - łączna produktywność w roku $t=0$,

$\alpha_{1}, \alpha_{2}-$ parametry strukturalne modelu.

Po sprowadzeniu funkcji potęgowej do postaci logarytmicznej i odpowiednim przekształceniu otrzymano wzór na obliczenie wskaźnika TFP w postaci logarytmicznej:

$$
\ln A=\operatorname{in} T F P=\ln V-\alpha_{1} \ln L-\alpha_{2} \ln K
$$

Tak mierzona całkowita produktywność czynników jest uważana za miarę postępu technicznego. Postępem technicznym jest ta część całkowitej produkcji, która nie może być wyjaśniona przez proces akumulacji mierzalnych czynników produkcji takich jak kapitał i praca. Obliczone wskaźniki produktywności przedstawiono w tabeli 1.

W opracowaniu do analizy wybrano następujące czynniki produktywności: wynagrodzenia, nakłady inwestycyjne i innowacyjne oraz techniczne uzbrojenie pracy. Poziom nakładów inwestycyjnych oraz innowacyjnych przeliczono na zatrudnionego dla uzyskania porównywalności w przemyśle spożywczym i przetwórstwie przemysłowym. Dynamikę zmian zbadano za pomocą średniorocznego tempa zmian [Wysocki i Lira 2003, s. 134]. Do analizy zależności mię- 


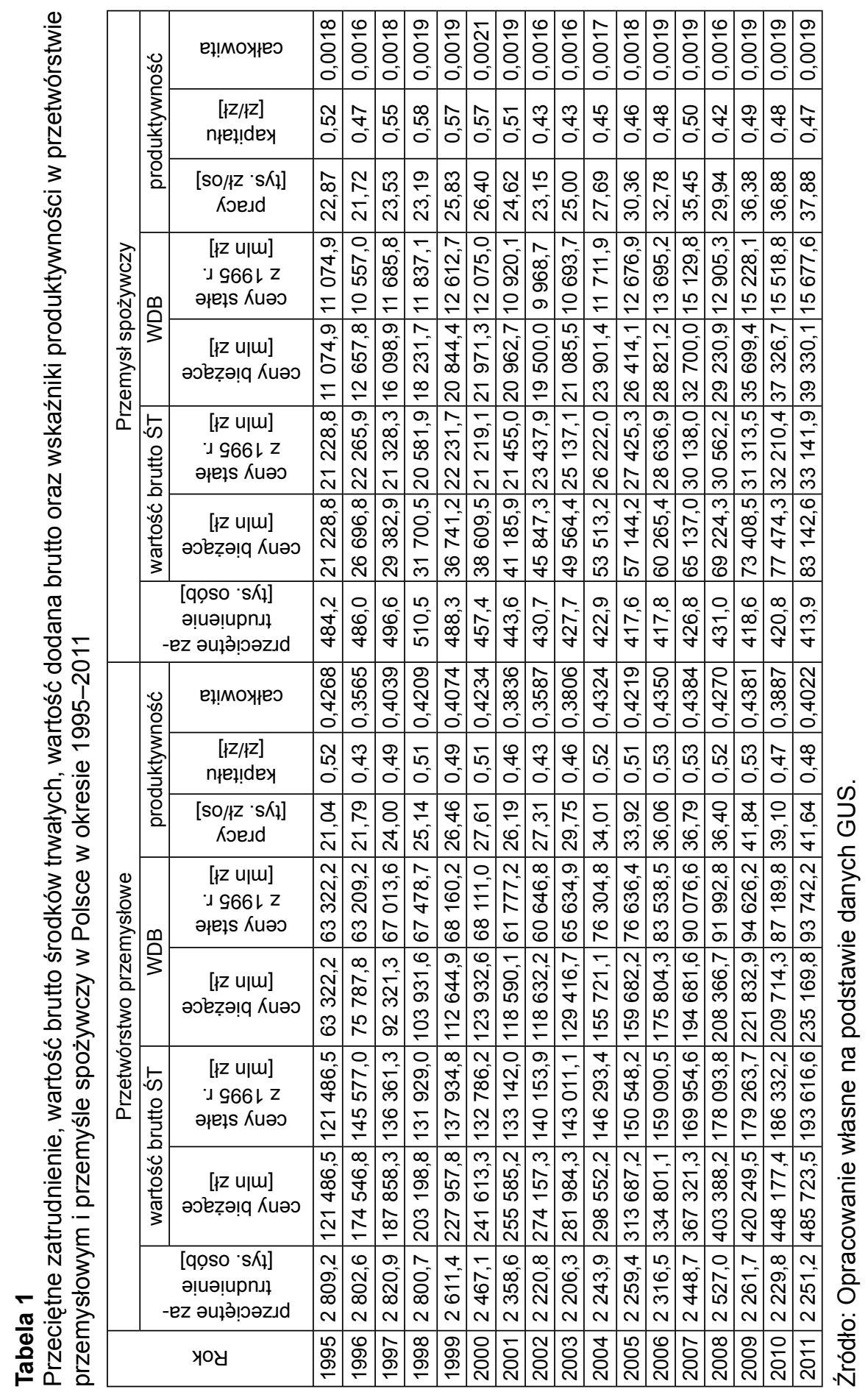




\section{8}

dzy wybranymi determinantami a wskaźnikami produktywności wykorzystano współczynnik korelacji liniowej Pearsona. Jego statystyczną istotność określono za pomocą testu $\mathrm{t}^{1}$. Dodatkowo analizę zależności rozszerzono o analizę regresji liniowej prostej o postaci:

$$
y=a_{0}+a_{1} x
$$

gdzie:

y - zmienna objaśniana (wskaźniki produktywności: produktywność pracy, produktywność kapitału, produktywność całkowita),

$x \quad$ - zmienna objaśniająca (determinanty: techniczne uzbrojenie pracy, wynagrodzenia, poziom nakładów innowacyjnych na zatrudnionego, poziom nakładów inwestycyjnych na zatrudnionego),

$a_{0}, a_{1}$ - parametry równania regresji.

Do oszacowania współczynników regresji zastosowano metodę najmniejszych kwadratów, a ocenę przydatności oszacowanych funkcji przeprowadzono na podstawie analizy współczynnika determinacji $\mathrm{R}^{2}$, który określa stopień dopasowania modelu do wyników obserwacji. Analizę zależności przeprowadzono w dwóch ujęciach, tj. w modelu bez opóźnienia czasowego oraz w modelu z rocznym opóźnieniem czasowym zmiennych objaśniających produktywność. W badaniu wykorzystano dane roczne dla lat 1995-2011 publikowane przez GUS. W obliczeniach posłużono się wartościami realnymi. Kategorie wyrażone w jednostkach pieniężnych sprowadzono, wykorzystując wskaźniki cen towarów i usług konsumpcyjnych, do cen stałych z 1995 roku.

\section{Wyniki badań i dyskusja}

Jednym z głównych czynników zwiększających zaangażowanie pracowników, w tym wydajność ich pracy jest wynagrodzenie. Stanowi ono zapłatę za pracę podporządkowaną i wykonywaną na rzecz pracodawcy [Borkowska 2004, s. 11] i obok funkcji dochodowej, kosztowej i społecznej pełni również funkcję motywacyjna. Przeprowadzona analiza statystyczna potwierdziła wpływ wynagrodzeń na produktywność pracy (tab. 2). Najsilniejszy liniowy związek o charakterze dodatnim wystapił w modelach bez opóźnienia czasowego (przemysł spożywczy: $\mathrm{R}=0,883, \mathrm{R}^{2}=0,779$, przetwórstwo przemysłowe: $\mathrm{R}=0,952$, $\left.\mathrm{R}^{2}=0,906\right)$.

\footnotetext{
${ }^{1}$ Statystyka $t$ ma postać $t=R \sqrt{(n-3) /\left(1-R^{2}\right)}$. Weryfikacji poddano hipotezę $H_{0}: R=0$ (zmienne nie są skorelowane) wobec hipotezy alternatywnej $H_{1}: R \neq 0$ (zmienne są skorelowane). Hipotezy zostały zweryfikowane na poziomie istotności $\alpha=0,05$.
} 


\section{Tabela 2}

Współczynniki korelacji liniowej oraz równania regresji liniowej między wskaźnikami produktywności a badanymi czynnikami w Polsce w okresie 1995-2011

\begin{tabular}{|c|c|c|c|}
\hline Wyszczególnienie & Produktywność całkowita & Produktywność pracy & Produktywność kapitału \\
\hline \multicolumn{4}{|c|}{ Model bez opóźnienia czasowego - przetwórstwo przemysłowe } \\
\hline Wynagrodzenia & $\begin{array}{c}R=0,223 \\
y=0,000008 x+0,392 \\
R^{2}=0,050\end{array}$ & $\begin{array}{c}R=0,952^{*} \\
y=0,009 x+13,757 \\
R^{2}=0,906\end{array}$ & $\begin{array}{c}R=0,164 \\
y=0,000007 x+0,480 \\
R^{2}=0,267\end{array}$ \\
\hline $\begin{array}{l}\text { Nakłady innowacyjne } \\
\text { na zatrudnionego }\end{array}$ & $\begin{array}{c}R=0,258 \\
y=0,004 x+0,389 \\
R^{2}=0,067\end{array}$ & $\begin{array}{c}R=0,892^{*} \\
y=3,183 x+13,884 \\
R^{2}=0,796\end{array}$ & $\begin{array}{c}R=0,200 \\
y=0,003 x+0,476 \\
R^{2}=0,040\end{array}$ \\
\hline $\begin{array}{l}\text { Nakłady inwestycyjne } \\
\text { na zatrudnionego }\end{array}$ & $\begin{array}{c}R=0,455 \\
y=0,003 x+0,375 \\
R^{2}=0,207\end{array}$ & $\begin{array}{c}R=0,941^{*} \\
y=1,399 x+13,220 \\
R^{2}=0,885\end{array}$ & $\begin{array}{c}R=0,404 \\
y=0,003 x+0,4579 \\
R^{2}=0,163\end{array}$ \\
\hline $\begin{array}{l}\text { Techniczne uzbrojenie } \\
\text { pracy }\end{array}$ & $\begin{array}{c}R=0,116 \\
y=0,0002 x+0,393 \\
R^{2}=0,0135\end{array}$ & $\begin{aligned} & R=0,955^{\star} \\
y= & 0,504 x-0,613 \\
& R^{2}=0,912\end{aligned}$ & $\begin{array}{c}R=0,057 \\
y=0,0001 x+0,485 \\
R^{2}=0,003\end{array}$ \\
\hline \multicolumn{4}{|c|}{ Model bez opóźnienia czasowego - przemysł spożywczy } \\
\hline Wynagrodzenia & $\begin{array}{c}R=0,196 \\
y=0,00000 x+0,002 \\
R^{2}=0,0386\end{array}$ & $\begin{aligned} & R=0,883^{*} \\
y= & 7,280 x+7,799 \\
& R^{2}=0,779\end{aligned}$ & $\begin{array}{c}R=-0,463 \\
y=-0,00004 x+0,556 \\
R^{2}=0,214\end{array}$ \\
\hline $\begin{array}{l}\text { Nakłady innowacyjne } \\
\text { na zatrudnionego }\end{array}$ & $\begin{array}{c}R=0,101 \\
y=0,000009 x+0,002 \\
R^{2}=0,01\end{array}$ & $\begin{array}{c}R=0,442 \\
y=0,904 x+3,727 \\
R^{2}=0,195\end{array}$ & $\begin{array}{c}R=-0,244 \\
y=-0,009 x+0,526 \\
R^{2}=0,059\end{array}$ \\
\hline $\begin{array}{l}\text { Nakłady inwestycyjne } \\
\text { na zatrudnionego }\end{array}$ & $\begin{array}{c}R=0,093 \\
y=0,000003 x+0,002 \\
R^{2}=0,009\end{array}$ & $\begin{array}{c}R=0,832^{*} \\
y=1,288 x+12,897 \\
R^{2}=0,693\end{array}$ & $\begin{array}{c}R=-0,469 \\
y=-0,007 x+0,572 \\
R^{2}=0,220\end{array}$ \\
\hline $\begin{array}{l}\text { Techniczne uzbrojenie } \\
\text { pracy }\end{array}$ & $\begin{array}{c}R=0,056 \\
y=0,000001 x+0,002 \\
R^{2}=0,003\end{array}$ & $\begin{aligned} & R=0,921^{*} \\
y= & 0,379 x+6,269 \\
& R^{2}=0,849\end{aligned}$ & $\begin{array}{c}R=-0,585^{*} \\
y=-0,002 x+0,620 \\
R^{2}=0,342\end{array}$ \\
\hline \multicolumn{4}{|c|}{ Model z opóźnieniem czasowym 1 rok - przetwórstwo przemysłowe } \\
\hline Wynagrodzenia & $\begin{array}{c}R=0,325 \\
y=0,00001 x+0,383 \\
R^{2}=0,105\end{array}$ & $\begin{array}{c}R=0,943^{*} \\
y=0,009 x+14,994 \\
R^{2}=0,888\end{array}$ & $\begin{array}{c}R=0,277 \\
y=0,00001 x+0,468 \\
R^{2}=0,277\end{array}$ \\
\hline $\begin{array}{l}\text { Nakłady innowacyjne } \\
\text { na zatrudnionego }\end{array}$ & $\begin{aligned} & R=0,517^{\star} \\
& y= 0,007 x+0,369 \\
& R^{2}=0,268\end{aligned}$ & $\begin{array}{c}R=0,950^{*} \\
y=3,163 x+14,821 \\
R^{2}=0,903\end{array}$ & $\begin{array}{c}R=0,473 \\
y=0,008 x+0,451 \\
R^{2}=0,224\end{array}$ \\
\hline $\begin{array}{l}\text { Nakłady inwestycyjne } \\
\text { na zatrudnionego }\end{array}$ & $\begin{aligned} & R=0,541^{*} \\
y= & 0,003 x+0,367 \\
& R^{2}=0,292\end{aligned}$ & $\begin{array}{c}R=0,930^{*} \\
y=1,337 x+15,081 \\
R^{2}=0,865\end{array}$ & $\begin{aligned} & R=0,504^{*} \\
y= & 0,447 x+0,003 \\
& R^{2}=0,254\end{aligned}$ \\
\hline $\begin{array}{l}\text { Techniczne uzbrojenie } \\
\text { pracy }\end{array}$ & $\begin{array}{c}R=0,353 \\
y=0,0008 x+0,358 \\
R^{2}=0,125\end{array}$ & $\begin{array}{c}R=0,951^{*} \\
y=0,523 x-0,432 \\
R^{2}=0,905\end{array}$ & $\begin{array}{c}R=0,308 \\
y=0,001 x+0,447 \\
R^{2}=0,095\end{array}$ \\
\hline
\end{tabular}


cd. tabeli 2

\begin{tabular}{|c|c|c|c|}
\hline Wyszczególnienie & Produktywność całkowita & Produktywność pracy & Produktywność kapitału \\
\hline \multicolumn{4}{|c|}{ Model z opóźnieniem czasowym 1 rok - przemysł spożywczy } \\
\hline Wynagrodzenia & $\begin{array}{c}R=0,136 \\
y=0,000000 x+0,002 \\
R^{2}=0,019\end{array}$ & $\begin{array}{c}R=0,864^{*} \\
y=0,008 x+15,504 \\
R^{2}=0,746\end{array}$ & $\begin{array}{c}R=-0,510^{*} \\
y=-0,000043 x+0,563 \\
R^{2}=0,26\end{array}$ \\
\hline $\begin{array}{l}\text { Nakłady innowacyjne } \\
\text { na zatrudnionego }\end{array}$ & $\begin{array}{c}R=0,415 \\
y=0,00004 x+0,002 \\
R^{2}=0,172\end{array}$ & $\begin{array}{c}R=0,570^{*} \\
y=2,148 x+20,428 \\
R^{2}=0,324\end{array}$ & $\begin{array}{c}R=-0,081 \\
y=-0,003 x+0,501 \\
R^{2}=0,007\end{array}$ \\
\hline $\begin{array}{l}\text { Nakłady inwestycyjne } \\
\text { na zatrudnionego }\end{array}$ & $\begin{array}{c}R=0,251 \\
y=0,00001 x+0,002 \\
R^{2}=0,063\end{array}$ & $\begin{array}{c}R=0,872^{*} \\
y=1,391 x+12,424 \\
R^{2}=0,761\end{array}$ & $\begin{array}{c}R=-0,327 \\
y=-0,005 x+0,548 \\
R^{2}=0,107\end{array}$ \\
\hline $\begin{array}{l}\text { Techniczne uzbrojenie } \\
\text { pracy }\end{array}$ & $\begin{array}{c}R=0,073 \\
y=0,000001 x+0,002 \\
R^{2}=0,005\end{array}$ & $\begin{array}{c}R=0,923^{*} \\
y=0,402 x+5,791 \\
R^{2}=0,852\end{array}$ & $\begin{array}{c}R=-0,505^{\star} \\
y=-0,002 x+0,607 \\
R^{2}=0,255\end{array}$ \\
\hline
\end{tabular}

* Współczynniki korelacji istotne na poziomie $\alpha=0,05$.

Źródło: Opracowanie własne na podstawie danych GUS.

W całym analizowanym okresie wysokość przeciętnego wynagrodzenia w przemyśle spożywczym była niższa niż w przetwórstwie przemysłowym (rys. 1). Na tożsame relacje wskazuje również Mroczek [2012, s. 63]. Najkorzystniej relacja kształtowała się w 2009 roku - na poziomie 92,28\%. W okresie 1995-1999 realny wzrost płac wynosił 9,63\% w przemyśle spożywczym i $10,17 \% \mathrm{w}$ przetwórstwie przemysłowym. W okresie bezpośrednio poprzedzającym przystapienie Polski do UE wzrost wynagrodzeń uległ wyhamowaniu (odpowiednio 1,11 i 1,34\% rocznie w latach 2000-2003), a następnie przyspieszeniu w pierwszych latach członkowstwa w Unii Europejskiej (odpowiednio 4,12 i 4,39\% rocznie w latach 2004-2008). Zdaniem Judzińskiej [2011, s. 47], wzrost wynagrodzeń wynikał z korzystnej koniunktury gospodarczej, wyższych zysków przedsiębiorstw oraz poprawy wydajności pracy przy niewielkim wzroście zatrudnienia. W kolejnych latach spowolnienie koniunktury gospodarczej w Polsce wywołane światowym kryzysem finansowym spowodowało ponowne wyhamowanie tempa wzrostu wynagrodzeń $(1,54 \%$ rocznie w przemyśle spożywczym i 2,32\% w przetwórstwie przemysłowym w latach 2009-2011). Znaczenie wynagrodzeń w zwiększaniu zaangażowania pracowników i motywowania ich do bardziej intensywnej pracy, a co za tym idzie do wyższej wydajności podkreśla również Zakrzewska [2010, s. 260]. Zauważyła ona, że w okresie 2000-2008 najwyższe przeciętne wynagrodzenie w przemyśle spożywczym otrzymywali zatrudnieni w przemysłach paszowym, napojów i olejarskim, a więc w tych grupach przemysłu spożywczego, w których poziom i wzrost wydajności pracy były 


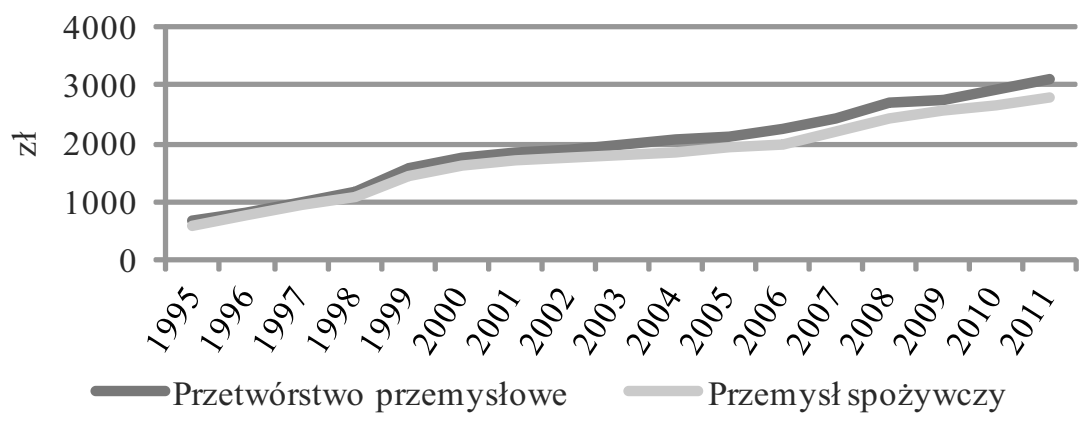

\section{Rysunek 1}

Przeciętne wynagrodzenie [zł] w przemyśle spożywczym i przetwórstwie przemysłowym w latach 1995-2011

Źródło: Opracowanie własne na podstawie danych GUS.

największe. Najniższą zapłatę za pracę uzyskiwali natomiast pracownicy przemysłu mięsnego i rybnego, a więc branż przemysłu spożywczego o najniższym poziomie produktywności pracy.

Obok czynników związanych z zasobami ludzkimi znaczącą rolę we wzroście produktywności stanowią czynniki związane z materialno-techniczną bazą wytwórczą, technologią produkcji i środkami pracy. Analiza korelacji i regresji potwierdziła zależność pomiędzy poziomem nakładów inwestycyjnych a poziomem produktywności pracy w przemyśle spożywczym $\left(\mathrm{R}=0,872 \mathrm{i} \mathrm{R}^{2}=0,761\right.$ $\mathrm{W}$ modelu $\mathrm{z}$ opóźnieniem 1 rok) i przetwórstwie przemysłowym $\left(\mathrm{R}=0,941 \mathrm{i} \mathrm{R}^{2}\right.$ $=0,8854 \mathrm{w}$ modelu bez opóźnienia czasowego). Przeprowadzone badania wskazały również na zależność między poziomem nakładów inwestycyjnych a poziomem produktywności całkowitej $\left(\mathrm{R}=0,541, \mathrm{R}^{2}=0,292\right)$ oraz między poziomem nakładów inwestycyjnych a poziomem produktywności kapitału $(R=0,504$, $\left.\mathrm{R}^{2}=0,255\right) \mathrm{w}$ przetwórstwie przemysłowym $\mathrm{w}$ modelach $\mathrm{z}$ rocznym opóźnieniem czasowym.

Poziom nakładów inwestycyjnych w przeliczeniu na zatrudnionego w latach 1995-1997 był wyższy w przemyśle spożywczym niż w całym przetwórstwie przemysłowym (rys. 2). W 1998 roku relacja ta uległa odwróceniu, a w kolejnych latach poziom wydatków na inwestycje na zatrudnionego w przemyśle spożywczym był względnie stały i utrzymywał się na podobnym poziomie jak w przetwórstwie przemysłowym. Duże ożywienie inwestycyjne w przemyśle spożywczym wywołało wstąpienie Polski do UE, które wiązało się z koniecznością dostosowania przedsiębiorstw do unijnych wymogów, przede wszystkim w zakresie bezpieczeństwa produkcji żywności i ochrony środowiska. Wartość inwestycji w przeliczeniu na zatrudnionego wzrosła w 2003 roku o 18,80\% 


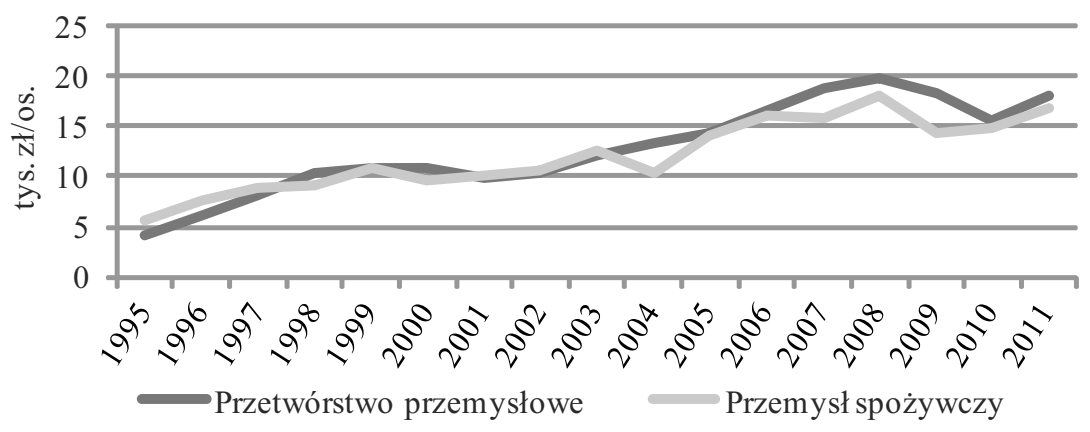

\section{Rysunek 2}

Nakłady inwestycyjne [tys. zł/os.] w przemyśle spożywczym i przetwórstwie przemysłowym w latach 1995-2011 (ceny stałe z 1995 r.)

Źródło: Opracowanie własne na podstawie danych GUS.

w stosunku do roku poprzedniego. Średnie tempo wzrostu w latach 2000-2003 wynosiło $9,97 \%$ rocznie, podczas gdy w przetwórstwie przemysłowym 3,79\%. W efekcie wielkość nakładów inwestycyjnych w przeliczeniu na zatrudnionego w 2003 roku w przemyśle spożywczym była większa o 5,78\% w porównaniu do przetwórstwa przemysłowego. Kociszewski i Szwacka-Mokrzycka [2011, s. 71] wskazują, że w okresie transformacji przetwórstwa spożywczego oraz integracji Polski z UE potencjał wytwórczy sektora został znacząco rozbudowany, zmodernizowany i unowocześniony. Przeprowadzone obliczenia wskazują, że w latach 2004-2011, pomimo dalszej aktywności inwestycyjnej producentów artykułów spożywczych, poziom nakładów inwestycyjnych w tym sektorze był ponownie niższy niż w całym przetwórstwie przemysłowym. Szczególnie niekorzystnie sytuacja kształtowała się w 2009 roku, kiedy to poziom nakładów w przeliczeniu na zatrudnionego był niższy o ok. $22 \% \mathrm{w}$ porównaniu do przetwórstwa przemysłowego. Obniżenie poziomu inwestycji nie było bynajmniej podyktowane brakiem środków finansowych (zyski przedsiębiorstw spożywczych w latach 2009-2010 należały do najwyższych od 2000 r.), a bardziej ostrożną polityką inwestowania prowadzoną przez przedsiębiorstwa [Florek 2013, s. 34]. Zachowania przedsiębiorstw spowodowane były także obawą o utratę płynności i ograniczeniami popytu, czego efektem był silny spadek nowych inwestycji [Chechelski i Judzińska 2011, s. 71]. W 2011 roku można było zaobserwować ponowny wzrost aktywności inwestycyjnej. W ujęciu realnym inwestycje w przeliczeniu na zatrudnionego w przemyśle spożywczym wzrosły o $14 \% \mathrm{w}$ stosunku do roku poprzedniego i były o tylko o $6 \%$ niższe niż w przetwórstwie przemysłowym.

Zwiększanie możliwości produkcji i produktywności czynników produkcji, obok wynagrodzeń i inwestycji, zależy również od wprowadzanych inno- 
wacji, które przyczyniać się mogą do zmian sposobu wytwarzania towarów czy ulepszania procesów produkcyjnych. Przeprowadzone obliczenia wskazują na występowanie zależności pomiędzy poziomem nakładów innowacyjnych a poziomem produktywności pracy w przetwórstwie spożywczym $(\mathrm{R}=0,570$, $\left.\mathrm{R}^{2}=0,324\right)$ i przetwórstwie przemysłowym $\left(\mathrm{R}=0,950, \mathrm{R}^{2}=0,90\right) \mathrm{w}$ modelu z rocznym opóźnieniem czasowym. Dodatnią i istotną statystycznie korelację odnotowano również pomiędzy poziomem nakładów innowacyjnych a poziomem produktywności całkowitej w przetwórstwie przemysłowym $(\mathrm{R}=0,517$, $\left.\mathrm{R}^{2}=0,268\right) \mathrm{w}$ modelu $\mathrm{z}$ rocznym opóźnieniem czasowym.

$\mathrm{W}$ analizowanym okresie poziom nakładów innowacyjnych w przeliczeniu na zatrudnionego $\mathrm{w}$ przemyśle spożywczym był znacznie niższy niż w całym przetwórstwie przemysłowym (rys. 3). OECD na podstawie wysokości nakładów na $\mathrm{B}+\mathrm{R}$ w stosunku do wartości sprzedanej zalicza przemysł spożywczy do sektorów niskiej techniki. Nie należy więc oczekiwać tego samego typu dokonań technicznych $\mathrm{w}$ przemyśle spożywczym co np. w przemyśle lotniczym [Adamowicz 2008, s. 7], jednak innowacje stają się ważnym czynnikiem konkurencyjności przemysłu spożywczego. Zdaniem Zuzek [2010, s. 444], czynniki tradycyjne, takie jak: wielkość produkcji, cena, trwałość i niezawodność wyrobu oraz redukcja kosztów wytwarzania samego wyrobu przestają odgrywać pierwszoplanową rolę, a w ich miejsce pojawiają się nowe czynniki powiązane z wiedzą i innowacyjnością. Biorąc pod uwagę przyrost nakładów na działalność innowacyjną należy stwierdzić, że jest on niższy w przedsiębiorstwach przemysłu spożywczego w porównaniu do przetwórstwa przemysłowego. Nakłady na działalność innowacyjną w przeliczeniu na zatrudnionego w okresie 1995-2011 rosły w przemyśle spożywczym średnio o 5,38\% rocznie, podczas gdy w przed-

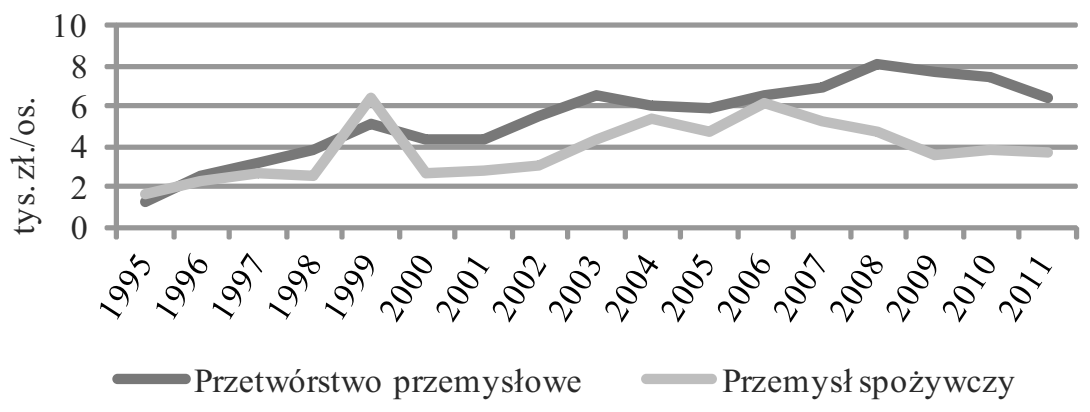

\section{Rysunek 3}

Nakłady innowacyjne [tys. zł/os.] w przemyśle spożywczym i przetwórstwie przemysłowym w latach 1995-2011 (ceny stałe z 1995 r.)

Źródło: Opracowanie własne na podstawie danych GUS. 


\section{4}

siębiorstwach przemysłowych wzrost ten był dwukrotnie większy $(10,69 \%)$. Zwiększenie aktywności innowacyjnej przedsiębiorstw przemysłu spożywczego można było zaobserwować w związku z przystąpieniem Polski do Unii Europejskiej. Wydatki na innowacje wzrastały w okresie 2000-2004 średnio o 18,84\% rocznie, podczas gdy w przetwórstwie przemysłowym o 8,45\%. Od 2007 roku w przemyśle spożywczym nastąpiło wyraźne zmniejszenie się nakładów na działalność innowacyjną w przeliczeniu na zatrudnionego. W 2009 roku stanowiły one zaledwie $47 \%$, w 2010 roku 52\%, a w 2011 roku 58\% nakładów innowacyjnych w przetwórstwie przemysłowym. Spadek nakładów innowacyjnych, podobnie jak w przypadku zmniejszenia inwestycji, wiązał się z wynikającą z kryzysu gospodarczego niepewnością panującą na światowym rynku żywności.

W strukturze nakładów na innowacje w przemyśle spożywczym dominowały wydatki na zakup oraz modernizację maszyn i urządzeń technicznych. $Z$ badań Matras-Bolibok [2009, s. 264] wynika, że w 2007 roku udział nakładów inwestycyjnych ponoszonych na zakup oraz modernizację maszyn i urządzeń służących wdrażaniu innowacji stanowił $63 \%$ i był o 5 p.p. wyższy niż w przedsiębiorstwach przemysłowych ogółem. Niepokojąco niski jest natomiast udział wydatków przedsiębiorstw przemysłu spożywczego na działalność B+R. W 2007 roku wyniósł on zaledwie 2,6\% ogółu nakładów, podczas gdy w przedsiębiorstwach przemysłowych $9,37 \%$. Świadczy to o tym, że przedsiębiorstwa przemysłu spożywczego są bardziej zainteresowane nabywaniem technologii materialnej niż generowaniem i nabywaniem nowej wiedzy. Takie zachowania wynikały najpierw z konieczności dostosowania się przedsiębiorstw do unijnych standardów produkcyjnych, a potem z potrzeby niwelowania luki technologicznej dzielącej polskie przedsiębiorstwa od firm z krajów wysoko rozwiniętych [Szczepaniak 2010, s. 6]. W kontekście analizy innowacyjności istotna jest również kwestia, jak nakłady innowacyjne przekładają się na efekty ekonomiczne. Matras-Bolibok [2009, s. 266] wskazuje, że w latach 2003-2007 poziom efektywności nakładów na działalność innowacyjną w przemyśle spożywczym stanowił zaledwie $73 \%$ średniego poziomu dla przedsiębiorstw przetwórstwa przemysłowego, gdzie z każdej złotówki poniesionych nakładów na działalność innowacyjną osiągnięto niemal 10 zł produkcji sprzedanej. Z badań Juchniewicz [2008, s. 95] wynika, że również efektywność działalności innowacyjnej przedsiębiorstw przemysłu spożywczego mierzona wartością produkcji sprzedanej wyrobów nowych i zmodernizowanych na 1 zatrudnionego jest niska. Przykładowo w 2005 roku była niższa od analogicznej wielkości w przetwórstwie przemysłowym 2,1-krotnie.

W kontekście badania produktywności czynników produkcji istotna jest również relacja między majątkiem a zasobami pracy, którą odzwierciedla wskaźnik technicznego uzbrojenia pracy. Wzrost tego wskaźnika wiąże się ze zwiększaniem wyposażenia majątkowego i jest przykładem kapitałochłonnych źródeł 
wzrostu wydajności pracy [2010, s. 262]. Przeprowadzone badania wskazują na pozytywny wpływ technicznego uzbrojenia pracy na produktywność pracy zarówno $\mathrm{w}$ przemyśle spożywczym $\left(\mathrm{R}=0,923, \mathrm{R}^{2}=0,852\right)$, jak i przetwórstwie przemysłowym $\left(\mathrm{R}=0,955, \mathrm{R}^{2}=0,912\right)$.

W początkowym okresie analizy wartość technicznego uzbrojenia pracy wykazywała różnokierunkowe wahania (rys. 4). Wyraźna tendencja wzrostowa rozpoczęła się w 1999 roku, a największy wzrost nastąpił w okresie poprzedzającym przystapienie Polski do UE. W latach 2000-2003 techniczne uzbrojenie pracy rosło średnio o $8,21 \%$ rocznie, czyli o 1,9 p.p. szybciej niż w przetwórstwie przemysłowym. Po przystapieniu Polski do UE można było zaobserwować dalszy szybki wzrost technicznego uzbrojenia pracy (w okresie 2004-2008 średnio $3,41 \%$ rocznie w przemyśle spożywczym wobec $1,97 \% \mathrm{w}$ przetwórstwie przemysłowym ogółem). W efekcie wartość środków trwałych przypadająca na jednego pracownika w latach 2008-2009 była w przemyśle spożywczym średnio o 1,18\% większa niż w przetwórstwie przemysłowym ogółem. W 2010 i 2011 roku w wyniku wyższej dynamiki wzrostu wartości brutto środków trwałych w przetwórstwie przemysłowym niż w przemyśle spożywczym relacja ta uległa ponownemu odwróceniu.

Wzrost technicznego uzbrojenia pracy w przemyśle spożywczym wiązał się nie tylko ze wzrostem produktywności pracy, ale również ze zmniejszeniem się produktywności kapitału $\left(\mathrm{R}=-0,585, \mathrm{R}^{2}=0,342\right)$. Wynikał $\mathrm{z}$ jednoczesnego zmniejszania zatrudnienia oraz wzrostu wartości środków trwałych będącego następstwem ponoszonych inwestycji na modernizację i unowocześnianie materialno-technicznej bazy wytwórczej. Zaobserwować można było zatem pro-

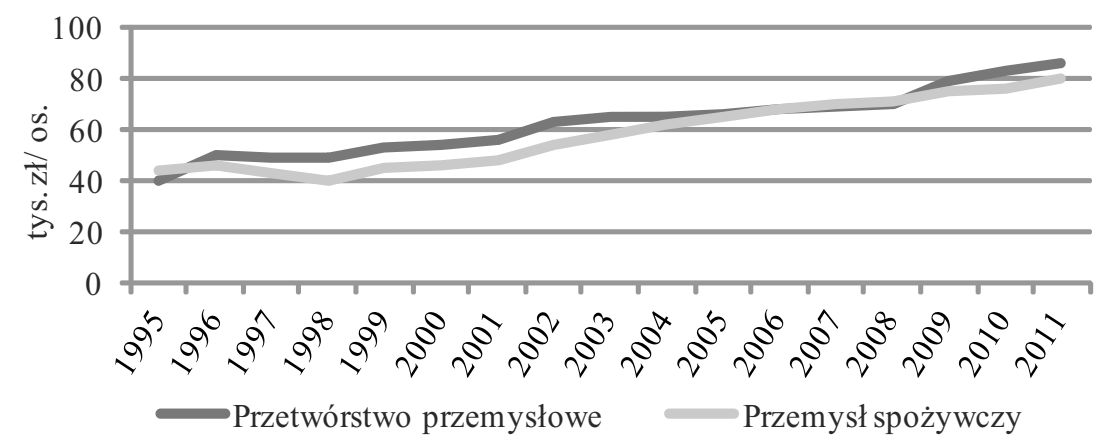

\section{Rysunek 4}

Poziom technicznego uzbrojenia pracy [tys. zł/os] w przemyśle spożywczym i przetwórstwie przemysłowym w latach 1995-2011 (ceny stałe z 1995 r.)

Źródło: Opracowanie własne na podstawie danych GUS. 


\section{6}

ces substytucji pracy przez kapitał. Tożsame wnioski występowały w analizach Adamczyka [2008, s. 102]. Zdaniem Juchniewicz i Urbana [2012, s. 143], nastąpiła reorientacja przemysłu spożywczego z tradycyjnego i bardziej pracochłonnego na nowocześniejszy i bardziej kapitałochłonny.

\section{Wnioski}

Przeprowadzone badania wskazują na pozytywny wpływ wynagrodzeń, nakładów innowacyjnych oraz technicznego uzbrojenia pracy na produktywność pracy w przemyśle spożywczym i przetwórstwie przemysłowym. Poziom nakładów innowacyjnych na zatrudnionego oddziaływał na produktywność pracy w perspektywie jednego roku od momentu ich poniesienia. Zaobserwowano również związek między nakładami innowacyjnymi i inwestycyjnymi a poziomem produktywności całkowitej (z opóźnieniem 1 roku) oraz między nakładami inwestycyjnymi i produktywnością kapitału w przetwórstwie przemysłowym. Nie udało się natomiast potwierdzić takich zależności w przemyśle spożywczym.

Poziom analizowanych czynników produktywności był generalnie niższy w przemyśle spożywczym niż w przetwórstwie przemysłowym. Pozytywne zmiany w zakresie nakładów na inwestycje i innowacje oraz technicznego uzbrojenia pracy można było zaobserwować w związku z integracją Polski do UE. Ze względu na konieczność dostosowania przedsiębiorstw do unijnych standardów, a $\mathrm{w}$ późniejszym etapie również niwelowania luki technologicznej dzielącej polskie przedsiębiorstwa od przedsiębiorstw z krajów wysoko rozwiniętych nastąpiło wyraźne ożywienie inwestycyjne oraz wzrost aktywności innowacyjnej. Innowacyjność przemysłu spożywczego wiązała się głównie z nabywaniem innowacyjnych maszyn i urządzeń, czyli technologii materialnej. Procesy modernizacji rozpoczęły się jeszcze w okresie przedakcesyjnym przy jednoczesnym wyhamowaniu wzrostu wynagrodzeń. Po akcesji procesy unowocześniania aparatu wytwórczego były kontynuowane przy jednoczesnym przyspieszeniu tempa wzrostu wynagrodzeń. W okresie kryzysu gospodarczego można było zauważyć przejściowe obniżenie aktywności inwestycyjnej i ponowne wyhamowanie tempa wzrostu wynagrodzeń. W efekcie ponoszonych wydatków inwestycyjnych i unowocześniania bazy wytwórczej w polskim przemyśle spożywczym nastąpił jednakże znaczący wzrost technicznego uzbrojenia pracy oraz substytucja pracy przez kapitał. Przemysł spożywczy stał się dzięki temu nowoczesny i kapitałochłonny. W dalszej perspektywie, w celu wzrostu produktywności i konkurencyjności przemysłu spożywczego, wydaje się konieczne podejmowanie działań zmierzających do wprowadzania innowacji nietechnologicznych oraz tworzenia, nabywania i rozpowszechniania wiedzy i wartości niematerialnych. 


\section{Literatura}

ADAMCZYK P., 2008: Produktywność czynników wytwórczych w przemyśle spożywczym $w$ Polsce, Zeszyty Naukowe SGGW. Ekonomika i Organizacja Gospodarki Żywnościowej 71, s. 95-106.

ADAMOWICZ M., 2008: Innowacje i innowacyjność w sektorze agrobiznesu. Rodzaje innowacji, Tom 2, Wydawnictwo SGGW, Warszawa.

BORKOWSKA S., 2004: Wynagrodzenia - rozwiazywanie problemów w praktyce, Oficyna Ekonomiczna, Kraków.

CHECHELSKI P., JUDZIEŃSKA A., 2011: Wpływ kryzysu na polski przemyst spożywczy, IERiGŻ-PIB 552, Warszawa.

FLOREK J., 2013: Nakłady inwestycyjne w polskim przemyśle spożywczym w latach 2000-2011, Zeszyty Naukowe SGGW Ekonomika i Organizacja Gospodarki Żywnościowej 104, s. 29-39.

JUCHNIEWICZ M., 2008: Innowacyjność jako czynnik wzrostu konkurencyjności polskiego przemystu spożywczego, [w:] Ocena rozwoju konkurencyjności polskich producentów żywności po integracji z Uniq Europejska, (red.) I. Szczepaniak, IERiGŻ, Warszawa.

JUCHNIEWICZ M., URBAN R., 2012: Ocena wplywu produktywności i efektywności na pozycję konkurencyjna przemystu spożywczego, [w:] Monitoring i ocena konkurencyjności polskich producentów żywności (2), (red.) I. Szczepaniak, IERiGŻ-PIB, Warszawa, 134-150.

JUDZIŃSKA A., 2011: Zatrudnienie $i$ wynagrodzenia $w$ przemyśle spożywczym, [w:] Procesy dostosowawcze polskiego przemystu spożywczego do zmieniajacego się otoczenia rynkowego (1), (red.) R. Mroczek, IERiGŻ-PIB, Warszawa, s. 42-51.

KOCIESZEWSKI M., SZWACKA-MOKRZYCKA J., 2011: Uwarunkowania rozwoju przemystu spożywczego po przystapieniu Polski do UE, Zeszyty Naukowe SGGW. Problemy Rolnictwa Światowego 11(26), z. 2, 67-77.

MATRAS-BOLIBOK A., 2009: Efektywność działalności innowacyjnej przedsiębiorstw przemystu spożywczego $w$ Polsce, SERiA t. XI, z. 1, 262-267.

MROCZEK R. (red.), 2012: Procesy dostosowawcze polskiego przemystu spożywczego do zmieniajacego się otoczenia rynkowego (2), IERiGŻ-PIB, Warszawa.

Rocznik Statystyczny Przemysłu 1996-2002, GUS, Warszawa.

SZCZEPANIAK I., 2010: Ekonomiczna ocena innowacyjności przedsiębiorstw przemystu spożywczego, Przemysł Spożywczy 64(11), s. 4-8.

WYSOKI F., LIRA J., 2003: Statystyka opisowa, Wydawnictwo Akademii Rolniczej im. A. Cieszkowskiego, Poznań.

ZAKRZEWSK A., 2010: Zróżnicowanie efektywności grup przemystu spożywczego w Polsce. Roczniki Nauk Rolniczych, Seria G, t. 97, z. 4, 258-266.

ZUZEK D.K., 2010: Innowacje produktowe w sektorze MSP przemystu spożywczego w Polsce jako istotny czynnik konkurencyjności, SERiA, t. XII, z. 3, s. 444-448. 


\title{
Influence of selected factors on resource productivity in manufacturing in Poland with regard to food processing
}

\begin{abstract}
The study assesses the level of selected factors and their impact on the productivity of the food industry against the background of manufacturing in the years 1995-2011. The influence of wages, investment, innovation and technical infrastructure on labor productivity in manufacturing and food industries was observed. The impact of investment and innovation on total productivity, as well as investment in capital productivity and innovation on labor productivity in manufacturing was revealed (correlation coefficients were high and statistically significant). The coefficients of determination in most of these cases showed a good fit of regression models to empirical data. The level of productivity factors was generally lower in the food industry than in manufacturing. However, there was an increase in investment activity and innovation and technical equipment working in the food industry during the Polish accession to the EU. However, to continue productivity growth of the food industry in the long term, it will be necessary to make non-technological innovation.
\end{abstract}

